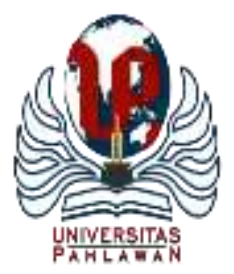

\title{
JURNALBASICEDU
}

Volume 6 Nomor 1 Tahun 2022 Halaman 354 - 363

Research \& Learningin Elementary Education https://jbasic.org/index.php/basicedu

\section{Analisis Kesesuaian Buku Tematik Sekolah Dasar dengan Kurikulum 2013}

\author{
Winu Galih Puspito ${ }^{1 凶}$, Anam Sutopo ${ }^{2}$, Anatri Desstya ${ }^{3}$ \\ Magister Pendidikan Dasar, Universitas Muhammadiyah Surakarta, Indonesia ${ }^{1,2,3}$ \\ E-mail: Winugalih23@gmail.com ${ }^{1}, \underline{\text { Anam.sutopo@ums.ac.id }}^{2}, \underline{\text { Ad121@ums.ac.id }}^{3}$
}

\begin{abstract}
Abstrak
Penelitian ini bertujuan untuk mendeskripsikan: 1) Kesesuaian Kompetensi Inti Buku tematik Kelas IV tema 7 dengan kurikulum 2013, 2) Kesesuaian Kompetensi Dasar Buku tematik Kelas IV tema 7 dengan kurikulum 2013, 3) Kecakupan materi Buku Tematik Kelas IV Tema 7 dengan kurikulum 2013. Jenis penelitian ini menggunakan penelitian kualitatif. Informan pada penelitian ini adalah guru kelas IV. Teknik pengumpulan data menggunakan wawancara dan metode analisis. Pengujian keabsahan data yang di peroleh menggunakan triangulasi sumber dan teknik. Hasil penelitian menunjukan bahwa: 1) Kompetensi Inti Buku Tematik Kelas IV tema 7 sudah sesuai dengan kurikulum 2013,2) Kompetensi Dasar Buku Tematik Kelas IV tema 7 sudah sesuai dengan kurikulum 2013, dan 3) Kecakupan materi pada semua mata pelajaran memperoleh persentase 99,16\% dengan kriteria sangat sesuai.
\end{abstract}

Kata Kunci: Analisis, Buku Tematik, Kurikulum 2013.

Abstract

This study aims to describe: 1) The suitability of the Core Competencies of thematic Books Grade IV theme 7 with the 2013 curriculum, 2) The suitability of the Basic Competencies of Grade IV thematic books with the 2013 curriculum, 3) Coverage of the material for the Grade IV Thematic Books, Theme 7 with the 2013 curriculum. This type of research uses qualitative research. Informants in this study were fourth grade teachers. Data collection techniques using interviews and analytical methods. Testing the validity of the data obtained using triangulation of sources and techniques. The results showed that: 1) Core Competencies of Grade IV Thematic Books theme 7 were in accordance with the 2013 curriculum, 2) Basic Competencies of Grade IV Thematic Books, theme 7 were in accordance with the 2013 curriculum, and 3) Coverage of material in all subjects obtained a percentage of $99,16 \%$ with very suitable criteria.

Keywords: Analysis, Thematic Books, Curriculum 2013

Copyright (c) 2022 Novita Winu Galih Puspito, Anam Sutopo, Anatri Desstya

$\triangle$ Corresponding author :

Email: Winugalih23@gmail.com

DOI : https://doi.org/10.31004/basicedu.v6i1.1911

ISSN 2580-3735 (Media Cetak)

ISSN 2580-1147 (Media Online) 


\section{PENDAHULUAN}

Pendidikan merupakan suatu proses yang memiliki arah tujuan (Pratama et al., 2019). Tujuan prioritas utama pendidikan adalah dalam rangka meningkatkan kualitas sumber daya manusia (SDM) untuk keberlanjutan pembangunan nasional (Sari et al., 2018). Pentingnya peran pendidikan terhadap keberlangsungan SDM pada masa mendatang menjadi acuan pemerintah untuk senantiasa melakukan peningkatan mutu pendidikan. Dalam upaya peningkatan mutu pendidikan pemerintah melakukan pembaharuan kurikulum. Perubahan dan pembaharuan kurikulum harus mengikuti perkembangan serta menyesuaikan kebutuhan masyarakat guna menghadapi tantangan global kedepan. Menurut Undang-undang No. 20 tahun 2003 tentang Sistem Pendidikan Nasional pasal 1 ayat 19 kurikulum adalah seperangkat rencana dan pengaturan mengenai tujuan, isi dan bahan pelajaran serta cara yang digunakan sebagai pedoman penyelenggaaraan kegiatan pembelajaran untuk mencapai tujuan pendidikan tertentu.

Kurikulum yang diterapkan pada saat ini adalah kurikulum 2013 menggantikan kurikulum KTSP (Kurikulum Tingkat Satuan Pendidikan). Pergantian kurikulum KTSP dengan kurikulum 2013 membuktikan bahwa masih adanya kekurangan dalam kurikulum KTSP. Sejalan dengan hal tersebut Prastowo (2013:216) mengungkapkan bahwa kurikulum yang selama ini digunakan dianggap belum mampu membekali siswa secara utuh, baik dari aspek intelektual, emosional, dan spiritual. Alhasil, pendidikan selama ini tidak berhasil membentuk siswa menjadi orang yang berkarakter, cakap, dan cerdas. Sedangkan (Mu'arif et al., 2021) menyatakan perubahan kurikulum dilakukan karena sifat kurikulum yang dinamis guna memaksimalkan kebutuhan mereka yang belajar. Untuk itu perlu diberlakukan kurikulum yang sesuai dan bisa memenuhi kebutuhan siswa secara menyeluruh dan Kurikulum 2013 adalah jawaban atas kebutuhan tersebut.

Keberhasilan kurikulum 2013 sangat dipengaruhi dari berbagai faktor dan melibatkan berbagai komponen. Mulyasa (2013:9) mengungkapkan bahwa kurikulum 2013 yang berbasis karakter dan kompetensi harus melibatkan semua komponen, termasuk komponen-komponen yang ada dalam sistem. Komponen tersebut meliputi kurikulum, proses belajar mengajar, pengelolaan sekolah, kesiapan guru serta seluruh warga yang berada disekolah dan penyediaan sarana prasarana. Sarana prasarana adalah satu komponen yang berperan besar dalam pencapaian tujuan pendidikan. Salah satu sarana dalam mencapai tujuan pendidikan dan masih menjadi sumber belajar penting hingga saat ini yaitu buku.

Buku pelajaran masih menjadi sumber belajar yang sangat penting bagi para peserta didik, terutama bagi sekolah-sekolah yang berada di luar kota, di pedesaan, dan di daerah-daerah terpencil, Mulyasa (2013:50). Pentingnya buku sebagai salah satu sumber belajar menjadi tanggung jawab guru agar dapat memilih buku yang sesuai guna memenuhi kebutuhan peserta didik, karena tidak semua buku mempunyai kualitas isi yang sesuai dengan kebutuhan. Kualitas buku dapat diamati dari relevansi terhadapt kurikulum, kejelasan konsep, menarik bagi peserta didik, mudah dipahami, menciptakan keaktifan peserta didik, serta menunjang nilai karakter. Diberlakukanya kurikulum baru maka buku yang digunakan dalam membantu proses pembelajaran juga harus disesuaikan.

Kementrian Pendidikan dan Kebudayaan Republik Indonesia (KEMENDIKBUD) telah menerbitkan buku pegangan guru dan siswa. Peraturan Menteri Pendidikan dan Kebudayaan Nomor 71 Tahun 2013 tentang Buku Teks Pelajaran dan Buku Panduan Guru untuk Pendidikan Dasar dan Menengah Pasal 1 Ayat 1 dan 2 yang menyatakan :

“(1) Menetapkan Buku Teks Pelajaran sebagai buku siswa yang layak digunakan dalam pembelajaran tercantum dalam Lampiran I yang merupakan bagian yang tidak terpisahkan dari Peraturan Menteri ini; (2) Menetapkan Buku Panduan Guru sebagai buku guru yang layak digunakan dalam pembelajaran tercantum dalam Lampiran II yang merupakan bagian yang tidak terpisahkan dari Peraturan Menteri ini". 
Peraturan Menteri Pendidikan Nasional Nomor 11 Tahun 2005 Bab I Pasal 2 Ayat 1 tentang Buku Teks Pelajaran yang menyatakan bahwa buku teks pelajaran digunakan sebagai acuan wajib oleh guru dan siswa dalam proses pembelajaran. Buku yang telah diterbitkan ini berbeda dengan buku sebelumnya. Kurikulum 2013 yang bersifat tematik integratif, maka setiap mata pelajaran sudah tidak berdiri sendiri melainkan saling berkaitan dan masuk dalam sebuah tema.Buku tematik yang menjadi pegangan guru dan siswa mengalami beberapa kali revisi hampir pada setiap tahun. Revisi merupakan petunjuk bahwa masih adanya kekurangan dalam buku tersebut. Kekurangan dalam buku tersebut dapat diketahui melalui kegiatan analisis.

Guru hendaknya selalu melakukan kegiatan analisis untuk mengatasi jika dimungkinkan ada kekurangan pada buku yang digunakan. Namun, kegiatan analisis tersebut belum sepenuhnya dilakukan oleh guru. Kurniasih (2014:10) mengungkapkan bahwa guru belum sepenuhnya melakukan tugas menganalisis Standar Kompetensi Lulusan (SKL), Kompetensi Inti (KI), Kompetensi Dasar (KD), buku siswa, dan buku guru dan banyak guru hanya menjadi plagiat dalam peristiwa ini atau menggunakan langsung buku tanpa menganalisis terlebih dahulu. Peraturan Menteri Pendidikan Dan Kebudayaan (PERMENDIKBUD) No. 37 Tahun 2018 dapat menjadi acuan dalam menganalisis buku. Permendikbud tersebut merupakan perubahan atas peraturan menteri pendidikan dan kebudayaan nomor 24 tahun 2016 tentang Kompetensi Inti dan Kompetensi Dasar pelajaran pada kurikulum 2013 pada pendidikan dasar dan pendidikan menengah.

Berdasarkan wawancara kepada Oky Prayogi, S.Pd, Guru kelas IV SDN 6 Kota Metro Lampung, Beliau menuturkan bahwa langsung menggunakan buku guru dan buku Siswa saat pembelajaran, serta belum sepenuhnya melakukan kegiatan analisis kesesuaian buku tersebut dengan Kurikulum 2013. Namun, beliau pernah menemukan ketidaksesuaian antara buku guru dan buku peserta didik. Ketidaksesuaian tersebut ditemukan pada buku tematik siswa kelas 4 tema 1 "Indahnya Kebersamaan", dimana pada pembelajaran kedua SBdP tidak tersedia KD 4.10 Memperagakan makna gerak ke dalam bentuk tari bertema dengan mengacu pada gaya tari daerah berdasarkan ruang gerak.

Latar belakang di atas memberikan inspirasi serta menjadi sebuah urgensi yang penting untuk dilaksanakannya telaah kesesuaian buku guru dan buku siswa agar tujuan kurikulum 2013 dapat terwujud. Pentingnya Tujuan kurikulum 2013 dapat terwujud guna mencetak generasi yang produktif, kreatif, inovatif, berkarakter serta serta mampu berkontribusi pada kehidupan bermasyarakat, berbangsa, bernegara, dan peradaban dunia. Oleh sebab itu peneliti mencoba untuk menganalisis kesesuaian buku guru dan buku siswa kelas iv sd/mi tema 7 indahnya keragaman di negeriku dengan kurikulum 2013. Dalam penelitian ini dilakukan analisis kesesuaian KI, KD, dan kecakupan materi buku tematik kelas IV tema 7 indahnya keragaman di negeriku dengan KI dan KD kurikulum 2013 mengacu pada PERMENDIKBUD No. 37 Tahun 2018.

Analisis kesesuaian buku tematik sekolah dasar pernah dilakukan oleh (Yunianto, 2021) dengan judul Analisis Kesesuaian Materi IPA Dalam Buku Siswa Kelas IV Semester 1 SD/MI Dengan Kurikulum 2013. Perbedaan dengan peneliti yaitu pada penelitian tersebut membahas kesesuaian muatan IPA sedangkan dalam penelitian ini membahas kesesuaian semua muatan pelajaran dengan kurikulum 2013. Selanjutnya penelitian (Septiani, 2021) yang berjudul Kesesuaian Materi Pembelajaran Dengan Kompetensi Dasar Pada Buku Tematik Tema 3 Kelas Iv Sekolah Dasar Edisi Revisi 2017. Penelitian tersebut menganalisis kesesuaian materi dengan Kompetensi Dasar (KD) sedangkan dalam penelitian ini menganalisis kesesuaian materi dengan Kompetensi Inti (KI) dan Kompetensi Dasar (KD).

Ketidaksesuaian buku akan berdampak dalam pemenuhan semua kebutuhan peserta didik. Padahal sejatinya dijelaskan dalam Peraturan Mentri Pendidikan Nasional (PERMENDIKNAS) Nomor 2 Tahun 2008 dikatakan bahwa buku berperan penting dan strategis dalam upaya meningkatkan mutu pendidikan. Oleh sebab itu untuk menjawab kesesuaian maupun tidak buku yang digunakan dapat dilakukan melalui kegiatan analisis. Namun kenyataanya, berdasarkan wawancara dikatakan bahwa guru belum sepenuhnya melakukan kegiatan analisis telaah kesesuaian buku sebelum melaksanakan pembelajaran. Berdasarkan hal tersebut, 
penelitian ini dilakukan untuk mengetahui kesesuaian buku tematik kelas IV tema 7 indahnya keragaman di negeriku.

\section{METODE PENELITIAN}

Penelitian ini menggunakan jenis penelitian kualitatif. Penekankan pada penelitian kualitatif lebih kepada proses yang bermakna dan bersifat deskripsi. Penelitian kualitatif mengkaji prespektif partisipan dengan multi strategi, strategi-strategi yang bersifat interaktif, seperti observasi langsung, observasi partisipatif, wawancara mendalam, dokumen-dokumen, teknik-teknik pelengkap seperti foto, rekaman, dll. (Sukmadinata, 2017). Sumber data dalam penelitian ini terbagi menjadi 2 data primer dan data sekunder. Data primer dalam penelitian ini adalah buku guru dan buku siswa tematik kelas IV tema "Indahnya Keragaman di Negeriku" terbitan Kementrian Pendidikan dan Kebudayaan (KEMENDIKBUD) revisi 2017. Data sekunder Data sekunder dalam penelitian ini adalah jurnal, artikel, serta undang-undang. Dalam penelitian ini kehadiran peneliti sangat berdampak terhadap keberhasilan analisis karena harus berinteraksi secara langsung dengan objek penelitian. Teknik pengumpulan data yang digunakan yaitu teknik observasi dan dokumentasi. Keabsahan data yang diperoleh diuji dengan menggunakan teknik triangulasi sumber. Teknik analisis data menggunakan model dari miles dan hubermen melalui analisis interaktif, (Sugiyono, 2019:321).

Prosedur penelitian dilakukan dengan cara: peneliti memandingkan KI dan KD buku guru dengan PERMENDIKBUD No. 37 Tahun 2018. Data yang diperoleh dimasukan ke dalam instrumen yang digunakan yaitu Instrumen checklist untuk menjawab kesesuaian KI dan KD. Selanjutnya kecakupan materi dilakukan analisis menggunakan skala likert dengan 3 item penilaian yaitu sangat sesuai, sesuai sebagian, dan sangat tidak sesuai. Masing-masing item mempunyai skor 5 untuk item sangat sesuai, 3 sesuai sebagian, dan skor 1 pada item sangat tidak sesuai. Instrumen analisis dan langkah menghitung persentase serta menentukan kategori kesesuaian disajikan sebagai berikut:

Tabel 1. Lembar Analisis KI Dengan Permendikbud No 37 Tahun 2018

\begin{tabular}{|c|c|c|c|c|}
\hline \multirow{2}{*}{$\begin{array}{l}\text { KI } \\
\text { No }\end{array}$} & \multirow{2}{*}{$\begin{array}{c}\text { KI } \\
\text { PERMENDIKBU } \\
\text { D NO. 37 TAHUN } \\
2018\end{array}$} & \multirow{2}{*}{$\begin{array}{c}\text { KI } \\
\text { BUKU } \\
\text { GURU } \\
\text { REVISI } \\
\mathbf{2 0 1 7}\end{array}$} & \multirow{2}{*}{$\begin{array}{c}\text { ANALISIS } \\
\text { TEMUAN }\end{array}$} & KESESUAIAN \\
\hline & & & & $\begin{array}{cc}\text { SESUA } & \text { TIDAK } \\
\text { I } & \text { SESUAI }\end{array}$ \\
\hline 3. & & & & \\
\hline 4. & & & & \\
\hline & KESESUAI & N AKHIR & & SESUAI \\
\hline
\end{tabular}

Tabel 2. Lembar Analisis KD Dengan Permendikbud No 37 Tahun 2018

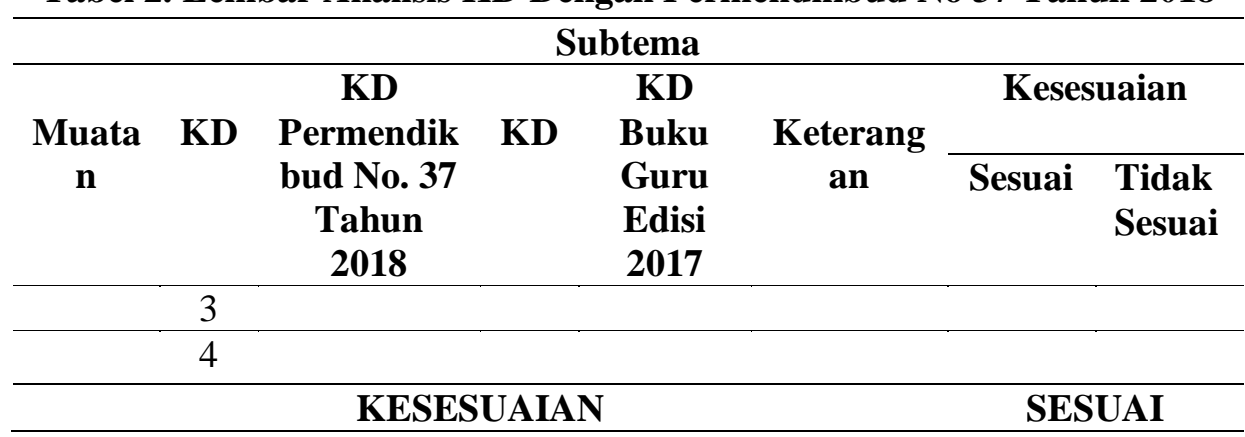


Tabel 3. Lembar Analisis Kecakupan Materi

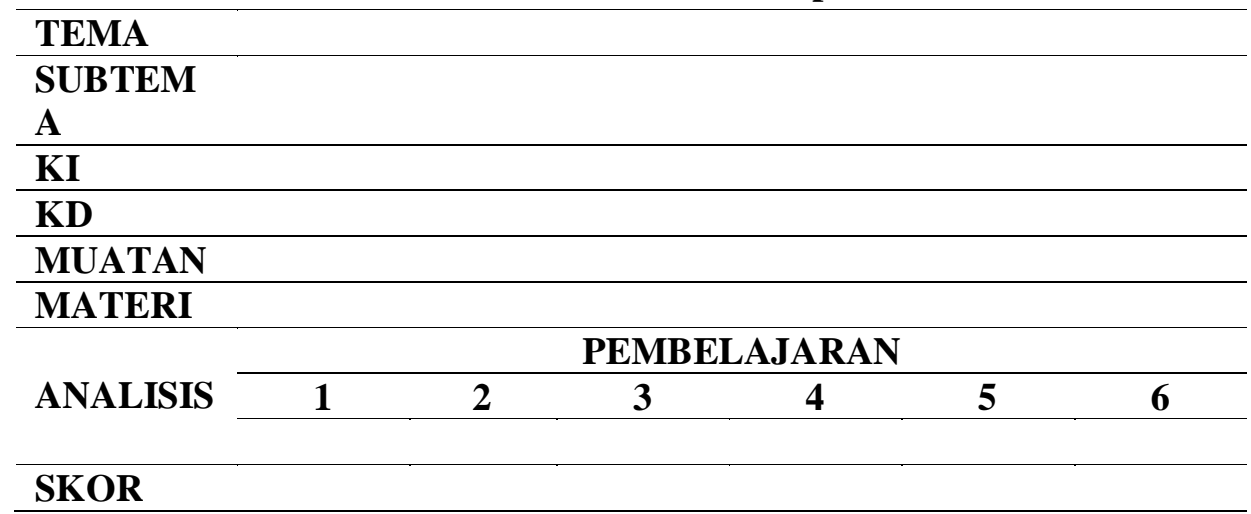

Untuk mengukur presentase kesesuaian kecakupan materi menggunakan rating scale, mengadopsi dari (Sugiyono, 2011) sebagai berikut:

$$
\begin{aligned}
& P K \\
& =\frac{\text { Skor yang diperoleh }}{\text { Skor maksimal }} \times 100 \%
\end{aligned}
$$

Sementara itu penentuan kategori kesesuaian menggunakan mengadopsi (Arikunto, 2013:35). Namun sebelum menentukan menentukan kategori kesesuaian Kecakupan materi terlebih dahulu membuat jenjang data kualitatif yang mengadopsi dari (Abidin, 2015) dengan langkah sebagai berikut :

a. Menentukan persentase nilai maksimal,

$$
\frac{\text { Skor maksimal }}{\text { Skor maksimal }} \text { X100\% }
$$

b. Menentukan persentase nilai minimal,

$$
\frac{\text { Skor minimal }}{\text { Skor maksimal }} X 100 \%
$$

c. Menentukan range,

Presentase nilai maksimal - presentase nilai minimal

d. Menentukan 3 interval yang diinginkan, yaitu sangat sesuai, sesuai sebagian, dan tidak sesuai

e. Menentukan lebar interval, dan

$$
\frac{\text { Range }}{\text { Jumlah Interval }}
$$

f. Membuat tabel presentase kategori kesesuaian.

\begin{tabular}{cc}
\hline Status Kesesuaian & Persentase \\
\hline Sangat Sesuai & $73,2 \%<\chi \leq 100 \%$ \\
\hline Sesuai & $46,6 \%<\chi \leq 73,2 \%$ \\
\hline Tidak Sesuai & $0 \%<\chi \leq 46,6 \%$ \\
\hline
\end{tabular}




\section{HASIL DAN PEMBAHASAN}

Analisis kesesuaian buku merupakan hal penting yang harus diperhatikan oleh guru sebelum pembelajaran. Analisis kesesuaian buku dapat membantu menemukan jika dimungkinkan adanya ketidak sesuaian buku yang nantinya ketidak sesuaian tersebut dapat menyebabkan kebutuhan siswa menjadi tidak terpenuhi secara maksimal. Oleh sebab itu, aktivias analisis tersebut harusnya bisa menjadi sebuah kebiasaan yang harus dilakukan guru sebelum pembelajaran dilaksanakan guna memperoleh buku berkualitas dalam berbagai bagian didalamnya, sehingga nantinya dapat menjawab semua kebutuhan siswa. Berdasarkan hasil analisis buku tematik kelas IV tema 7 indahnya keragaman di negeriku disajikan sebagai berikut.

\section{Kesesuaian Kompetensi Inti (KI)}

KI buku guru sudah sesuai dengan KI PEMENDIKBUD No 37 tahun 2018. Kesesuaian tersebut terlihat dengan tidak ditemukanya perbedaan berarti. Pada KI 3 buku guru terdapat penambahan kata (mendengar, melihat, membaca) setelah kata pengamatan. Meskipun terdapat perbedaan antara KI 3 Permendikbud dengan KI 3 guru masih sesuai, karena (mendengar, melihat, membaca) merupakan bagian dari aktivitas pengamatan. Kesesuaian ketiga kegiatan belajar (mendengar, melihat, membaca) dengan aktivitas pengamatan juga diungkapkan oleh (Kurniasari, 2017:13) yang mengungkapkan bahwa pada pengalaman belajar mengamati, kegiatan belajar yang dapat dilakukan peserta didik misalnya diminta membaca, mendengar, menyimak, melihat. Pada KI 4 buku guru terdapat penambahan tanda koma (,) setelah kata sistematis. Meskipun terdapat penambahan tanda koma (,) tidak merubah makna dan maksud dari tujuan Kompetensi Inti 3. Penambahan tanda koma (,) pada kata setelah sistematis di Kompetensi Inti 3 buku guru justru menambah kesesuaian pada kalimat tersebut. Setelah kata sistematis terdapat kata "dan". Kata tersebut merupakan kata yang bertindak sebagai konjungsi koordinatif dalam pemerincian, oleh sebab itu tanda baca koma diperlukan. Hal ini sesuai dengan pendapat (Sakir, 2021:37) yang menyatakan bahwa pada unsur-unsur pemerincian sebelum kata dan seharusnya menggunakan tanda koma.

\section{Kesesuaian Kompetensi Dasar (KD)}

KD buku guru sudah sesuai dengan KI PEMENDIKBUD No 37 tahun 2018. Kesesuaian tersebut terlihat dengan tidak ditemukanya perbedaan berarti KD pada semua muatan pelajaran (Bahasa Indonesia, PPKn, IPS, IPA, SBdP) dengan Permendikbud No 37 Tahun 2018. Ditemukan perbedaan penggunaan kata pada KD muatan SBdP. Peredaan tersebut pada penggunaan kata "Memerhatikan" dan "Memperagakan". Pada Kompetensi Dasar 4.2 buku guru menggunakan kata "Memerhatikan" sedangkan Kompetensi Dasar 4.2 Permendikbud menggunakan kata "Memperhatikan" serta perbedaan pada Kompetensi Dasar 4.3 buku guru yang menggunakan kata "Memperagakan" sedangkan Kompetensi Dasar 4.3 Permendikbud menggunakan kata "Meragakan". Kata dasar dari kata "Memerhatikan" dan "Memperhatikan" adalah hati bukan perhati. dengan begitu kata yang paling tepat digunakan adalah "Memperhatikan" karena adanya imbuhan memperkan. Peluluhan huruf "p" pada kata memperhatikan menjadi memerhatikan kurang tepat. Namun kedua kata tersebut masih memiliki makna yang sama. Sesuai dengan (Hima, 2017:221) mengatakan demikian bahwa "memperhatikan" termasuk bentuk yang baku dan "memerhatikan" bentuk yang tidak baku.

\section{Kecakupan Materi Buku Tematik Tema 7}

Kecakupan materi pada buku tematik tema 7 indahnya keragaman di negeriku juga sudah sesuai ditinjau dari KI dan KD Permendikbud No 37 Tahun 2018. Kesesuaian tersebut terlihat dari persentase perolehan skor masing-masing muatan pelajaran dan perolehan presentase akhir semua muatan pelajaran yang diakumulasikan sehingga didapatkan persentase dalam menentukan kategori kesesuaian. Untuk menghitung persentase dan menentukan kategori kesesuaian digunakan rumus dibawah ini. 
Untuk mengukur presentase kesesuaian kecakupan materi menggunakan rating scale, mengadopsi dari (Sugiyono, 2011) sebagai berikut:

$$
\begin{aligned}
& P K \\
& =\frac{\text { Skor yang diperoleh }}{\text { Skor maksimal }} X 100 \%
\end{aligned}
$$

Sementara itu penentuan kategori kesesuaian menggunakan mengadopsi (Arikunto, 2013:35). Namun sebelum menentukan menentukan kategori kesesuaian Kecakupan materi terlebih dahulu membuat jenjang data kualitatif yang mengadopsi dari (Abidin, 2015) dengan langkah sebagai berikut :

a. Menentukan persentase nilai maksimal,

$$
\frac{5}{5} X 100 \%=100 \%
$$

b. Menentukan persentase nilai minimal,

$$
\frac{1}{5} X 100 \%=20 \%
$$

c. Menentukan range, $100 \%-20 \%=80 \%$

g. Menentukan 3 interval yang diinginkan, yaitu sangat sesuai, sesuai sebagian, dan tidak sesuai

h. Menentukan lebar interval, dan

$$
\frac{80 \%}{3}=26,6 \%
$$

i. Membuat tabel presentase kategori kesesuaian.

\begin{tabular}{cc}
\hline Status Kesesuaian & Persentase \\
\hline Sangat Sesuai & $73,2 \%<\chi \leq 100 \%$ \\
\hline Sesuai & $46,6 \%<\chi \leq 73,2 \%$ \\
\hline Tidak Sesuai & $0 \%<\chi \leq 46,6 \%$ \\
\hline
\end{tabular}

Setelah menghitung dengan menggunakan rumus rating scale (Sugiyono, 2011) dan membandingkan dengan kategori kesesuaian cakupan masing-masing muatan materi didapatkan hasil sebagai berikut: Muatan materi Bahasa Indonesia memperoleh skor 180 dengan persentase 100\% dengan kategori sangat sesuai, Muatan materi IPS memperoleh skor 60 dengan persentase 100\% dengan kategori sangat sesuai, Muatan materi SBdP memperoleh skor 90 dengan persentase $100 \%$ dengan kategori sangat sesuai, Muatan materi PPKn memperoleh skor 88 dengan persentase 97,77\% dengan kategori sangat sesuai, Muatan materi IPA memperoleh skor 58 dengan persentase $96,66 \%$ dengan kategori sangat sesuai.

Terakhir dilakukan akumulasi data untuk mencari kesesuaian akhir cakupan materi buku tematik tema 7 indahnya keragaman di negeriku dengan memasukan semua skor muatan materi pelajaran $(180,60,90,88,58)$ ke dalam rumus rating scale dengan penyelesaian dibawah ini.

$$
\begin{aligned}
P K= & \frac{180+60+90+88+58}{480} X 100 \% \\
& =99,16 \%
\end{aligned}
$$


Berdasarkan data di atas kecakupan materi buku tematik kelas IV tema 7 indahnya keragaman di negeriku memperoleh presentase akhir 99,16\%. Dengan perolehan presentase 99,16\% kecakupan materi buku tematik tersebut memiliki kategori kesesuaian sangat sesuai. Presentase kesesuaian disajikan dalam diagram dibawah imi.

\section{Diagram 1. Kesesuaian Cakupan Materi Buku Tematik Kelas IV Tema Indahnya Keragaman Di Negeriku.}

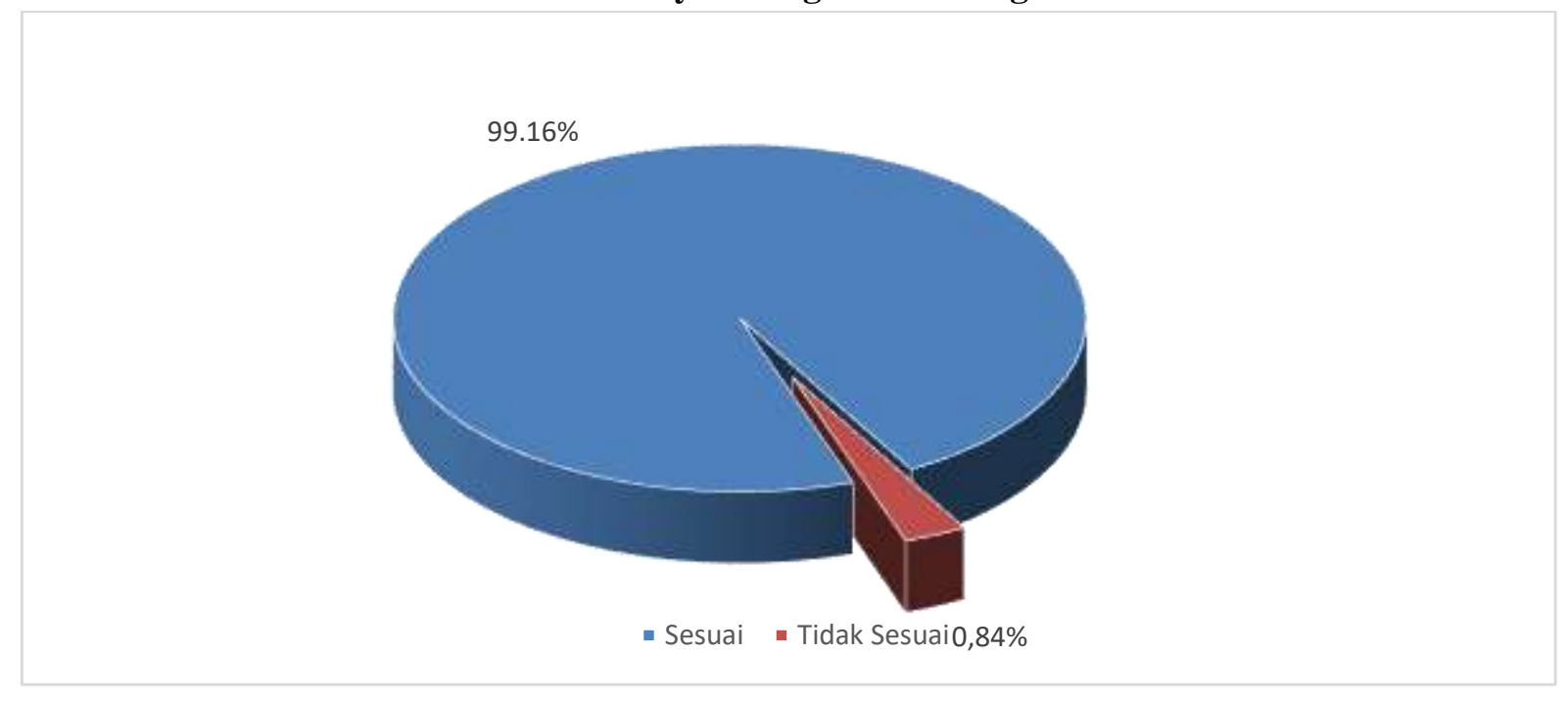

Diagram di atas menunjukan bahwa kesesuaian cakupan materi sebesar 99,16\% dan ketidak sesuaian relatif kecil yaitu $0,84 \%$. Meskipun terdapat ketidaksesuaian yang relatif kecil hendaknya ketidaksesuaian tersebut haruslah diatasi. Ketidaksesuaian tersebut terletak pada muatan PPKn dan IPA. KD 3.4 dan 4.4 muatan PPKn dalam buku guru subtema 3 pembelajaran 5 belum dimunculkan sedangkan pada pemetaan KD sudah tersedia. Selanjutnya pada KD 4.3 muatan IPA subtema 2 pembelajaran 2 kegiatan mendemonstrasikan manfaat gaya dalam kehidupan sehari-hari tidak tersedia atau belum dimunculkan. Ketidak sesuaian yang ditemukan dari hasil analisis buku tematik tema 7 indahnya keragaman di negeriku tersebut membuktikan bahwa sebelum pengunaan buku dalam pembelajaran hendaknya guru dapat melakukan telaah analisis terlebih dulu guna melihat sejauh mana buku tersebut sesuai dan jika ditemukan ketidak sesuaian maka hal tersebut dapat teratasi. Ketidak sesuaian muatan materi pelajaran buku tematik akan berpengaruh terhadap pemenuhan kebutuhan dan dikhawatirkan dapat menimpulkan miskonsepsi terhadap peserta didik. Sejalan dengan itu (Silviani et al., 2017) dalam penelitiannya mengungkapkan bahwa konsep materi pembelajaran yang tidak akurat akan menimbulkan miskonsepsi yang nantinya menghambat untuk menerima informasi yang baru.

Guru sebagai pengendali utama dalam pembelajaran di kelas hendaknya dapat selalu melakukan analisis buku yang digunakan sebelum melakukan pembelajaran sehingga buku tersebut dapat memenuhi kebutuhan peserta didik secara utuh serta mencapai tujuan yang diharapkan dalam pembelajaran dengan maksimal.

Hasil analisis buku tematik tema 7 indahnya keragaman di negeriku diharapkan dapat menjadi acuan dalam menggunakan bahan ajar pada saat kegiatan belajar mengajar (KBM) yang sesuai dengan standar kurikulum 2013. Memberikan motivasi guru dalam mengembangkan bahan ajar yang sesuai dengan kebutuhan peserta didik serta pada standar isi kurikulum 2013 dan tidak terpaku hanya pada bahan ajar yang tersedia saja. 


\section{KESIMPULAN}

Berdasarkan hasil penelitian dan pembahasan dapat disimpulkan bahwa buku tematik kelas IV tema indahnya keragaman di negeriku sudah sesuai dengan kurikulum 2013. Kesesuaian tersebut meliputi kesesuaian Kompetensi Inti (KI), Kompetensi Dasar (KD), dan kecakupan materi buku tematik kelas IV tema 7 dengan ditinjau dari Peraturan Mentri Pendidikan dan Kebudayaan (PERMENDIKBUD) No. 37 Tahun 2018. Kecakupan materi buku tematik kelas IV tema 7 memperoleh persentase hasil akhir 99,16\% dengan kriteria sangat sesuai.

\section{DAFTAR PUSTAKA}

Arikunto, S. (2013). Prosedur Penelitian Suatu Pendekatan Praktik. Rineka Cipta.

Hima, R. (2017). Kompetisi Bahasa Sebagai Wujud Eksistensi Bahasa Indonesia Di Era Masyarakat Ekonomi Asean (Mea) Rofiatul. Laboratorium Penelitian Dan Pengembangan Farmaka Tropis Fakultas Farmasi Universitas Mualawarman, Samarinda, Kalimantan Timur, 2(April), 5-24. Http://Jurnal.Unmuhjember.Ac.Id/Index.Php/Bb/Article/View/832

Kurniasari, F. (2017). Implementasi Pendekatan Saintifik Pada Penugasan Aktivitas Di Buku Teks Bahasa Indonesia Kelas Vii Smp Berdasarkan Kurikulum 2013. Jurnal Pendidikan Edutama, 4(1), 9-26. Https://Ejurnal.Ikippgribojonegoro.Ac.Id/Index.Php/Jpe/Article/View/44

Mu'arif, A. N., Damayanti, F., Akmalia, R., Arsfenti, T., \& Darmadi, D. (2021). Pengembangan Kurikulum 2013 Dalam Meningkatkan Pendidikan Karakter Di Sekolah Dasar. Edukatif: Jurnal Ilmu Pendidikan, 3(1), 44-57. Https://Doi.Org/10.31004/Edukatif.V3i1.164

Mulyasa. (2013). Pengembangan Dan Implementasi Kurikulum 2013 (P. 9). Pt Remaja Rosdakarya.

Permendikbud. (2005). Permendikbud Nomor 11 Tahun 2005.

Permendikbud. (2013). Peraturan Menteri Pendidikan Dan Kebudayaan Nomor 71 Tahun 2013.

Permendikbud. (2018). Permendikbud Ri Nomor 37 Tahun 2018 Tentang Perubahan Atas Peraturan Menteri Pendidikan Dan Kebudayaan Nomor 24 Tahun 2016 Tentang Kompetensi Inti Dan Kompetensi Dasar Pelajaran Pada Kurikulum 2013 Pada Pendidikan Dasar Dan Pendidikan Menengah. Jdih Kemendikbud, 2025, 1-527.

Permendiknas. (2008). Salinan Permendiknas No 2 Tahun 2008 Tentang Buku. 106-114.

Prastowo, A. (2013). Pengembangan Bahan Ajar Tematik (P. 216). Diva Press.

Pratama, F., Firman, \& Neviyarni. (2019). Pengaruh Motivasi Belajar Ipa Siswa Terhadap Hasil Belajar. Edukatif: Jurnal Ilmu Pendidikan, 1(3), 280-286. Https://Edukatif.Org/Index.Php/Edukatif/Article/View/63/0

Purbawanto, Z. A. \& S. (2015). Pemahaman Siswa Terhadap Pemanfaatan Media Pembelajaran Berbasis Livewire Pada Mata Pelajaran Teknik Listrik Kelas X Jurusan Audio Video Di Smk Negeri 4 Semarang. $\begin{array}{lllll}\text { Edu } & \text { Elektrika } & \text { Journal, } & \text { 38-49. }\end{array}$ Https://Journal.Unnes.Ac.Id/Sju/Index.Php/Eduel/Article/View/7800

Sakir, P. M. (2021). Analisis Penggunaan Ejaan Pada Teks Buku Paket Sejarah Kelas X Sma. Https://Ojs.Unm.Ac.Id/Titikdua/Article/View/23887

Sari, D. P., Febriani, O. M., \& Putra, A. S. (2018). Perancangan Sistem Informasi Sdm Berprestasi Pada Sd Global Surya. 289-294. Https://Jurnal.Darmajaya.Ac.Id/Index.Php/Psnd/Article/View/1260

Septiani, A., \& M, V. A. S. (2021). Kesesuaian Materi Pembelajaran Dengan Kompetensi Dasar Pada Buku Tematik Tema 3 Kelas Iv Sekolah Dasar Edisi Revisi 2017, 40-47. Https://Ejournal.Unsri.Ac.Id/Index.Php/Jisd/Article/View/14365 
363 Analisis Kesesuaian Buku Tematik Sekolah Dasar dengan Kurikulum 2013 - Novita Winu Galih Puspito, Anam Sutopo, Anatri Desstya

DOI: https://doi.org/10.31004/basicedu.v6i1.1911

Silviani, R., Muliyani, R., \& Kurniawan, Y. (2017). Penerapan Three Tier-Test Untuk Identifikasi Kuantitas Siswa Yang Miskonsepsi Pada Materi Magnet. Jipf (Jurnal Ilmu Pendidikan Fisika), 2(1), 10. Https://Doi.Org/10.26737/Jipf.V2i1.197

Sisdiknas. (2003). Undang-Undang Sistem Pendidikan Nasional.

Sugiyono. (2011). Metode Penelitian Pendidikan. Alfabeta.

Sugiyono. (2019). Metode Penelitian Kuantitatif Kualitatif Dan R\&D. Alfabeta.

Sukmadinata, N. S. (2017). Metode Penelitian Pendidikan. Pt Remaja Rodakarya.

Yunianto, T. (2021). Analisis Kesesuaian Materi Ipa Dalam Buku Siswa Kelas Iv Semester 1 Sd / Mi Dengan Kurikulum 2013 Analysis Of The Compatibility Of Science Materials In The First Semester Grade 4 Student Book Sd / Mi In Curriculum 2013 Pendahuluan Abad Ke-21 Yang Dikaitka. Viii (1), 1-17. 